Article Type: Original Article-Epidemiology of Allergic Disease

\title{
Incidence of food anaphylaxis in people with food allergy: a systematic review and meta-analysis
}

Thisanayagam Umasunthar MB ChB, Jo Leonardi-Bee PhD, Paul J. Turner BM BCh, PhD, Matthew Hodes MBBS, PhD, Claudia Gore MD, PhD, John O. Warner MD, FMed

Sci, Robert J. Boyle MB ChB, PhD.

Department of Paediatrics, Imperial College London (Dr Umasunthar, Dr Turner, Professor Warner, Dr Boyle); Imperial College Healthcare NHS Trust, St Mary's Hospital, London (Dr Umasunthar, Dr Turner, Dr Hodes, Dr Gore, Professor Warner, Dr Boyle); Division of Epidemiology and Public Health, University of Nottingham (Dr Leonardi-Bee); Centre for Mental Health, Imperial College London (Dr Hodes)

Corresponding Author:

Robert J Boyle

Wright Fleming Building

Norfolk Place

London W2 1PG

Tel: +44 2075943990 Fax: +44 207594 3984. Email: r.boyle@nhs.net

This article has been accepted for publication and undergone full peer review but has not been through the copyediting, typesetting, pagination and proofreading process, which may lead to differences between this version and the Version of Record. Please cite this article as doi: 10.1111/cea.12477

This article is protected by copyright. All rights reserved. 
Declaration of all sources of funding: Thisanayagam Umasunthar received salary support from Lincoln Medical. John Warner is supported by a National Institute for Health Research Senior Investigator Award. This work was supported by a National Institute for Health Research Biomedical Research Centre.

Conflict of Interest statement: Thisanayagam Umasunthar was supported by funding from Lincoln Medical; John Warner is a trustee of the Anaphylaxis Campaign; John Warner and Robert Boyle have received research funding from the UK Food Standards Agency; Robert Boyle has received a grant for conference attendance from Meda Pharmaceuticals; the authors report no other relationships or activities that could appear to have influenced the submitted work.

Author contributions: TU undertook the literature search and wrote the first draft of the manuscript, RJB designed the study, assisted with data collection and synthesis, and wrote the final draft of the manuscript. JLB assisted with study design and data analysis. All authors reviewed and commented on earlier versions of the manuscript.

Keywords: anaphylaxis; hospital admission; food allergy; systematic review

\section{Abstract}

Background: Food allergy is a common cause of anaphylaxis, but the incidence of anaphylaxis in food allergic people is unknown.

This article is protected by copyright. All rights reserved. 
Methods: We undertook a systematic review and meta-analysis, using the inverse variance method. Two authors selected studies by consensus, independently extracted data and assessed study quality using the Newcastle-Ottawa assessment scale. We searched Medline, Embase, PsychInfo, CINAHL, Web of Science, LILACS and AMED between January 1946 and September 2012, and recent conference abstracts. We included registries, databases or cohort studies which described the number of food anaphylaxis cases in a defined population and time period, and applied an assumed population prevalence of food allergy.

Results: We included data from 34 studies. There was high heterogeneity between study results, possibly due to variation in study populations, anaphylaxis definition and data collection methods. In food allergic people, medically-coded food anaphylaxis had an incidence rate of 0.14 per 100 person years $(95 \% \mathrm{Cl} 0.05,0.35$; range $0.01,1.28)$. In sensitivity analysis using different estimated food allergy prevalence, the incidence varied from 0.11 to 0.21 per 100 person years. At age $0-19$ the incidence rate for anaphylaxis in food allergic people was $0.20(95 \% \mathrm{Cl} 0.09,0.43$; range 0.01, 2.55; sensitivity analysis $0.08,0.39$ ). At age $0-4$ an incidence rate of up to 7.00 per 100 person years has been reported. In food allergic people, hospital admission due to food anaphylaxis had an incidence rate of $0.09(95 \% \mathrm{Cl} 0.01,0.67$; range $0.02,0.81)$ per 1000 person years; $0.20(95 \% \mathrm{Cl} 0.10,0.43$; range $0.04,2.25)$ at age $0-19$ and 0.50 $(0.26,0.93$; range $0.08,2.82)$ at age $0-4$.

This article is protected by copyright. All rights reserved. 


\section{Conclusion}

In food allergic people, the incidence of food allergic reactions which are coded as anaphylaxis by healthcare systems is low at all ages, but appears to be highest in young children.

\section{Introduction}

Food allergy affects up to $10 \%$ of children and $2-3 \%$ of adults, has a significant quality of life impact and appears to be increasing in prevalence in some countries. (1-3) Food allergy is the commonest cause of anaphylaxis, however the precise risk of anaphylaxis for food allergic people is not known. Uncertainty about the absolute level of risk associated with food allergy may be an important contributor to wider uncertainties over service provision for food allergy, food labelling legislation and allergen management strategies. In order to quantify the risk of anaphylaxis for food allergic people, we undertook a systematic review and meta-analysis. We estimated the incidence rate of self-reported anaphylaxis, of medically-coded anaphylaxis and hospital admission for food anaphylaxis in a food allergic individual. As part of the same project, we estimated the incidence rate of fatal anaphylaxis and have reported this elsewhere (4). We compared these risks with other age-specific risks for people living in the United States or Europe. We undertook subgroup analyses for young people (aged 0-19) with food allergy, and for peanut allergic people. In view of the uncertainty about food allergy prevalence in different populations, we undertook sensitivity analysis to explore the effect of varying food allergy prevalence estimates, on food anaphylaxis incidence.

This article is protected by copyright. All rights reserved. 


\section{Methods}

Data sources

This review was carried out and reported in accordance with the PRISMA guidelines for systematic reviews and meta-analyses (5). We searched Medline, Embase, PsycINFO, Web of Science, Allied and Complementary Medicine (AMED), Latin American and Caribbean Health Science Information database (LILACS) and Cumulative Index to Nursing and Allied Health Literature (CINAHL) for articles published between January 1946 and September 5th 2012 which described food anaphylaxis incidence - the Medline search strategy has been published elsewhere (4), and similar searches were used for other databases. We searched abstracts from the 2011 and 2012 meetings of the American Academy of Asthma Allergy and Immunology (AAAAI) and the European Academy of Allergy and Clinical Immunology (EAACl) using 'food allergy' and 'anaphylaxis'. We searched US national data (CDC Wonder, Centers for Disease Control and Prevention) and European Union-27 data (Eurostat, European Commission) for incidences of other sudden or emergency events. There was no registered protocol for this review, but the methods and analyses were planned a priori. No language restrictions were made, and we planned to include non-English papers if they met our inclusion criteria.

\section{Study selection}

Two authors (TU, RJB) independently screened titles and abstracts, and selected studies by consensus. We reviewed reference lists of included studies and review articles to identify any further studies. Inclusion criteria were: (i). Study design. 
Prospective or retrospective registries, databases or cohort studies. (ii). Participants. People with a medically diagnosed food allergy, or a defined population where an assumed population rate of food allergy could be applied. (iii). Follow up. To enable calculation of total person-years of observation, we included studies that specified either total population and duration of data collection, or anaphylaxis incidence rate. (iv).

Outcomes. We included reports of number of food anaphylaxis events during the follow up period. Exclusion criteria were: (i). food allergic reactions reported were not anaphylactic, or severity was not defined; (ii). time period not defined; (iii). population in which food anaphylaxis cases occurred could not be quantified. Studies needed to satisfy all 4 inclusion criteria and none of the exclusion criteria, to be included in the review. Where the population number was not described in the study, we derived total populations and populations aged 0-19 using regional public health databases. Where necessary we contacted authors for data clarification or original datasets.

\section{Data extraction}

Two authors (TU, RJB) independently extracted data, and quality assessed the included studies. Differences were resolved by discussion. When available, we separately extracted data for younger people (age 0-19), and those with peanut allergy. We estimated incidences for the total food allergic population, and subgroups of aged 0-19 years and peanut allergy. Where studies were restricted to a population aged $<19$, data were only used for the 0-19 subgroup, and likewise for peanut allergy. For quality assessment we used the Newcastle-Ottawa quality assessment scale for cohort studies with one modification.(6) Under the criterion 'was follow-up long enough for outcomes 
to occur' we considered studies with at least 20 cases of food anaphylaxis to satisfy this criterion. We separately recorded an extra quality criterion - whether diagnostic criteria for anaphylaxis used in each study were consistent with the consensus NIAID/FAAN definition (7). For studies of hospital admissions, we judged anaphylaxis definitions to be consistent with NIAID/FAAN criteria if they used ICD codes for anaphylaxis.(7) Studies were considered high quality if Newcastle-Ottawa score was at least 4, and anaphylaxis definition was consistent with the consensus definition. For analyses where all studies scored less than 4 , we undertook subgroup analysis excluding the poorest quality studies (ie score <2).

\section{Data synthesis}

For each study, number of events and total person-years of follow-up were extracted, and incidence rate was calculated as number of cases per 100 or 1000 person years. Rates were pooled across studies using the natural logarithm of the occurrence rate and its standard error (estimated using $1 /$ Vevents) based on a random effect model using the generic inverse variance method (STATA version 12 IC, Stata Corporation). Heterogeneity was assessed using $\mathrm{I}^{2}$. For meta-analyses including $\geq 10$ studies, we assessed publication bias using Funnel plots. We conducted meta-analysis even if significant heterogeneity was seen between study estimates, but explored possible reasons in sensitivity analyses, including study quality. For calculations we estimated the population food allergy prevalence as 3\% overall, $3.9 \%$ for a $0-19$ year old, $1 \%$ for peanut allergy, but explored the effect of different prevalence estimates in sensitivity analyses due to the considerable uncertainty in the literature surrounding food allergy

This article is protected by copyright. All rights reserved. 
prevalence in different populations. $(2,8-10)$ We assumed that all food anaphylaxis would occur in this population. We made no separate analysis of incidence according to sex, due to insufficient gender-specific data from included studies.

\section{Estimation of comparator risks}

We selected sudden unexpected occurrences with recent reliable population-based information as comparator risks using US and EU-27 data. Emergency department attendances for a motor vehicle accident (E810-E819, E958.5, E968.5, E988.5), total emergency department attendance rates, and attendances due to an injury (E800-E848, E850-E869, E880-E929) were extracted from National Center for Health Statistics data for 2006-2008 (CDC Wonder, Centers for Disease Control and Prevention). Fatality data including murder (X85-Y09), fire (X00-X09), all accidents (V01-99 or W00-X59), lightning (X33) and all cause mortality were extracted from the same data source for 2005-2007. European data using the same codes and time periods were extracted from Eurostat for the EU-27 population (Eurostat, European Union). The data used were not age-adjusted.

\section{Results}

Our search identified 2552 original titles. Title screening yielded 459 abstracts, and 156 full articles were reviewed for potential relevance. We identified 37 publications containing relevant data, and a further 5 publications from screening review articles and reference lists. Eight of these articles only reported fatal anaphylaxis events and were included in fatal anaphylaxis analyses reported elsewhere (4). The remaining 34 studies

This article is protected by copyright. All rights reserved. 
contributed to the analyses reported herein. Search results are shown in Figure 1, and characteristics of included studies in Table 1. All included studies contributed to at least one meta-analysis.

Incidence rate of self-reported food anaphylaxis in food allergic people We identified 10 studies including 9076 participants, where follow up data for the occurrence of food anaphylaxis in food allergic individuals were presented or could be derived.(11-20) Data for self-reported food anaphylaxis at all ages were only available from one study, where the estimated risk for a food allergic person was $8.59(95 \% \mathrm{Cl}$ $8.25,8.94)$ per 100 person years. (18) For those aged $0-19$, meta-analysis of data from all 10 studies gave an incidence of $4.93(2.78,8.74$; range $0.60,57.89)$ per 100 person years; one study (13) found an incidence of $9.27(7.83,10.98)$ per 100 person years for children aged 0-4 and for peanut allergic people meta-analysis of data from 4 studies gave an incidence rate of $2.64(1.13,6.17$; range $1.64,8.90)$ per 100 person years $(15$, 16, 19, 20) (Figures 3A, 5A). Meta-analyses showed a high level of heterogeneity, but there was no evidence of publication bias (Figure E1)..

Risk of medically coded food anaphylaxis in food allergic people We identified 13 surveys of medical attendances for food anaphylaxis, covering over 19.9 million person years. (21-33) Meta-analysis estimated the risk of medically-coded food anaphylaxis for a food allergic person as $0.14(95 \% \mathrm{Cl}$ 0.05, 0.35; range 0.01 , 1.28) per 100 person years overall based on 9 studies $(21,24-30,32) ; 0.20(0.09,0.43$; range $0.01,2.55)$ in those aged $0-19$ based on 9 studies $(21-23,26,28,30-33) ; 0.37$

This article is protected by copyright. All rights reserved. 
$(0.01,17.07$; range $0.03,7.03)$ in those aged $0-4$ based on 3 studies $(21,28,32)$; and $0.13(0.04,0.41$; range $0.01,0.54)$ in peanut allergy based on 6 studies $(21-23,28,32$, 33) (Figures 2A, 3B, 4A, 5B). All meta-analyses showed high levels of heterogeneity. The study of Tejedor found a much higher rate of food anaphylaxis than other studies, in food allergic children aged 0-4, for unclear reasons. (32) In sensitivity analysis with different estimated food allergy prevalence (Table 2), the mean incidence rate varied from 0.07 to 0.21 per 100 person years; 0.08 to 0.39 for those aged $0-19 ; 0.14$ to 0.72 for those aged 0-4. Our study quality sensitivity analysis excluded studies with modified Newcastle-Ottawa score under $4 / 5(21,31,33)$, or anaphylaxis definition inconsistent with the NIAID/FAAN consensus $(7,22,24,25,27,29,31)$. Here we found an increased rate of medically-coded food anaphylaxis in the total food allergic population -0.25 $(95 \% \mathrm{Cl} 0.06,1.12$; range $0.05,1.28)$; in $0-19$ year olds $-0.31(0.08,1.25$; range 0.03 , $2.55)$; in $0-4$ year olds $-1.35(0.05,37.57$; range $0.23,7.03)$ and for peanut allergy $0.18(0.09,0.36$; range $0.11,0.30)$ but heterogeneity of study outcomes remained significant.

Risk of hospital admission due to food anaphylaxis in food allergic people We identified 11 studies which reported food anaphylaxis admission rates, covering over 120 million people observed over several years.(34-44) Meta-analysis estimated the risk of food anaphylaxis admission for a food allergic person as $0.09(95 \% \mathrm{Cl} 0.01$, 0.67 ; range $0.02,0.81)$ per 1000 person years overall, based on 4 studies $(36,39,41$, 42); $0.20(0.10,0.43$; range $0.04,2.25)$ in those aged $0-19$ based on 8 studies (34-37, $40,42-44) ; 0.50(0.26,0.93$; range $0.08,2.82)$ in those aged $0-4$ based on 6 studies

This article is protected by copyright. All rights reserved. 
(34-36, 40-42) and $0.08(0.02,0.36$; range $0.02,0.69)$ in peanut allergy based on 5 studies (35, 37-39) (Figures 2B, 3C, 4B, 5C). All meta-analyses showed high levels of heterogeneity. In sensitivity analysis with different estimated food allergy prevalence, the incidence varied from 0.05 to 0.14 per 1000 person years; 0.08 to 0.39 for those aged $0-19 ; 0.19$ to 0.98 for those aged $0-4$. Our study quality sensitivity analysis excluded studies with a modified Newcastle-Ottawa score under $4 / 5(35,36)$, or anaphylaxis definition inconsistent with the NIAID/FAAN consensus $(7,35,36,44)$. Here we found increased incidence of food anaphylaxis admission in the total food allergic population $-0.16(95 \% \mathrm{Cl} 0.02,1.55$; range $0.03,0.81)$; in $0-19$ year olds -0.46 $(0.20,1.07$; range $0.04,2.25)$; in $0-4$ year olds $-0.98(0.53,1.82$; range $0.08,2.82)$ and in those with peanut allergy $-0.16(0.03,0.84$; range $0.05,0.69)$ but heterogeneity of study outcomes remained highly significant.

\section{Comparison of food allergy risks with other age-specific risks}

Figures E2A-B show the estimated annual incidence rate of food anaphylaxis for a food allergic person and a food allergic 0-19 year old, in comparison with incidence of other events for general US or European populations. The data suggest that the incidence of medically coded anaphylaxis for a food allergic person is greater than the general population incidence of accidental death, but is likely to be significantly lower than the incidence of Emergency Department attendance due to a motor vehicle accident.

This article is protected by copyright. All rights reserved. 


\section{Discussion}

In this systematic review we evaluated the incidence rate of anaphylaxis to food in people with food allergy, and compared our estimates with population incidence rates for other unexpected medical emergencies and causes of death. There was marked variation in the estimated rate of food anaphylaxis between studies, but at all ages and in all studies the incidence of medically coded anaphylaxis for food allergic people was low. We found evidence that food anaphylaxis rates are higher in preschool children with food allergy, where incidence rates varied significantly between studies, but were reported as up to 7 per 100 person years for medically-coded anaphylaxis, and 2.8 per 1000 person years for hospital admission due to anaphylaxis.

Food anaphylaxis is a medical emergency which occurs unpredictably and often involves young people. It causes alarm to the individual, family and carers due to its rapid clinical course, distressing symptoms and potential to cause a fatal reaction. Some people with food allergy and their families have restricted lives because of fear of anaphylaxis and fatal outcomes, which they may estimate to be more likely to occur than reality. (45) Accidental allergic reactions occur up to once per year in certain groups of food allergic people - our data suggest that severe, life-threatening allergic reactions occur much less frequently than this (13). The results of this study may help healthcare providers and their patients to more accurately appraise the risks of food allergy, and thereby make informed decisions about its management.

This article is protected by copyright. All rights reserved. 
We did not identify a marked difference in food anaphylaxis rates in those aged 0-19 or in those allergic to peanut, but we did note that the highest rates of medically coded food anaphylaxis and hospital admission for food anaphylaxis were seen in preschool children. This contrasts with the pattern seen for fatal food anaphylaxis, which is most common in adolescents and young adults, but has a very low incidence rate in the preschool years (personal communication, Richard Pumphrey). It is unclear why food anaphylaxis is more common in preschool children, but possible reasons include the high prevalence of food allergy at this age, and the possibility that food anaphylaxis is more common preceding a diagnosis of food allergy than subsequently. The wide variation in rates between studies suggests that variable hospital admission criteria and/or coding may also be relevant. Previous work has identified that those with asthma, previous severe reaction, IgE binding to a diverse range of epitopes, deficient platelet activating factor acetyl hydrolase or serum angiotensin-converting enzyme may be at increased risk for food anaphylaxis. (46-48) One might expect the frequency with which a food is used as an ingredient, and allergen avoidance behaviour to also influence risk for individuals. We found some evidence to support this from two studies with different rates of self-reported anaphylaxis for allergy to different foods. There was a lower anaphylaxis rate for fish than for other food allergens in one study (49) and a lower rate for egg than milk in another (13). Those with food allergy secondary to inhalant sensitization ('oral allergy syndrome'), without asthma, with previous mild reactions and beyond the preschool age group may be at lower risk of food anaphylaxis. It was not possible to separately assess food allergy caused by pollen-food crossreactivity in this study, due to limited data available in the included studies. More work is 
needed to identify tools for risk stratification and risk reduction in patients with food allergy. (50)

The limitations of this systematic review mainly relate to variations between studies in methods of data capture and classification of anaphylaxis, and limited information about food allergy prevalence in the populations studied. These sources of clinical and methodological heterogeneity were reflected in high levels of statistical heterogeneity in all analyses, which could not be explained by subgroup analysis according to age, specific food allergen or study quality. There is therefore some uncertainty about the precision of our risk estimates, so that the mean estimates should be interpreted with caution. The rate of self-reported anaphylaxis varied widely across studies, depending on the patient population enrolled and successfully followed up. Study quality was generally rated as low for studies of self-reported anaphylaxis, which generally occurred at less than 1 episode every 10 person years. There is a risk of over-reporting when relying on self-report of anaphylaxis and most of these studies enrolled patients from specialist allergy clinics, which may not be representative of all food allergic populations. The study of Gold reported a much higher rate of anaphylaxis than others, possibly due to a looser definition of anaphylaxis and small study size (14). Overall it is likely that studies of self-reported anaphylaxis over-estimate the true incidence of anaphylaxis, both due to the selected populations included, the nature of the methods of data collection, and the poor overall quality of included studies.

This article is protected by copyright. All rights reserved. 
The rate of medically coded anaphylaxis also varied widely between studies, due in part to differing diagnostic criteria and sampling methods. In the highest quality studies, medically coded anaphylaxis occurred at up to 1 episode every 100 person years in the general population, 2.5 episodes at age $0-19$, and 7 episodes at age $0-4$. These data may under-estimate food anaphylaxis occurrence because not all anaphylaxis reaches medical attention - however the study quality was higher than for self-reported anaphylaxis, and severe anaphylaxis which needs medical attention is likely to be captured, at least where clinical coding can be relied upon. This means that the figures are likely to provide a reasonably accurate picture of the healthcare burden of food anaphylaxis for a given population. The study of Tejedor reported higher rates of food (but not peanut) anaphylaxis than others (32). The reason for this is unclear, although the authors used a larger number of databases to search for anaphylaxis cases than some other studies. The wide variations which we found in hospital admission rates for food anaphylaxis may be attributed to varied clinical coding, clinical practice and healthcare behaviours and food allergy prevalence between studies and over time. (41, 42) Rates were highest in the Australian studies of Poulos and Mullins, which may reflect the high prevalence of food allergy in Australia $(1,40,41)$. Overall rates are likely to be an underestimate, due to the known problems with reliance on clinical coding for data collection. The true incidence rate of food anaphylaxis for a food allergic person is likely to be higher than the estimate derived from studies of medically-coded anaphylaxis, but lower than the estimate derived from studies of self-reported anaphylaxis.

This article is protected by copyright. All rights reserved. 
Given the limitations of population-based datasets and reliance on clinical coding of outcomes, it is likely that the most reliable estimates of food anaphylaxis incidence rate in food allergic people would come from detailed follow up and data capture/coding of representative groups of food allergic people. Although such datasets exist [13], the follow up studies which contributed to our meta-analyses were of uniformly poor quality, meaning that the rates of self-reported anaphylaxis may be unreliable. There is therefore a need for further longitudinal studies of representative food allergic populations to precisely assess the incidence rate of serious food allergic reactions.

For the purpose of our study we estimated that the prevalence of food allergy is $3 \%$ for adults, $3.9 \%$ for children, and $1 \%$ for peanut allergy. Food allergy prevalence varies considerably between studies, (51) so a lower prevalence would increase the incidence rates, and vice versa. Food allergy and peanut allergy were found to be more prevalent than our estimates in some recent birth cohorts. $(1,52)$ We therefore undertook sensitivity analyses to explore the effect of variations in population food allergy prevalence on our estimates (Table 2). Overall the sensitivity analyses did not lead to marked differences in the overall pattern of estimated food anaphylaxis incidence rates. Variations in population prevalence of food allergy may therefore not be the most important reason for the wide variation we found in food anaphylaxis rates between studies. In Table 3, we present a summary of our assessment of the systematic review outcomes, which takes account of the sensitivity analyses and limitations discussed above.

This article is protected by copyright. All rights reserved. 
In conclusion we have quantified the risk of food anaphylaxis for food allergic people, and found this to be low. With the exception of one small study with methodological limitations, all included studies reported food anaphylaxis incidence rate for food allergic people to be less than once every 10 person years. This information should help clinicians and their food allergic patients to make informed decisions with regard to risk management. These data also highlight the need to identify improved tools for anaphylaxis diagnosis and risk stratification in food allergy.

\section{Acknowledgments}

We would like to thank Drs Carlos Iribarren, Ray Mullins, Scott Sicherer, Michael Gold and Andrew Clark for providing original data or helping with data queries for this project, and Liz Callow for assistance with running the searches.

\section{References}

1. Osborne NJ, Koplin JJ, Martin PE, Gurrin LC, Lowe AJ, Matheson MC, et al. Prevalence of challenge-proven IgE-mediated food allergy using population-based sampling and predetermined challenge criteria in infants. Journal of Allergy and Clinical Immunology. 2011;127(3):668-76.e2.

2. Rona RJ, Keil T, Summers C, Gislason D, Zuidmeer L, Sodergren E, et al. The prevalence of food allergy: A meta-analysis. Journal of Allergy and Clinical Immunology. 2007;120(3):638-46.

3. Flokstra-de Blok BM, Dubois AE, Vlieg-Boerstra BJ, Oude Elberink JN, Raat H, DunnGalvin A, et al. Health-related quality of life of food allergic patients: comparison

This article is protected by copyright. All rights reserved. 
with the general population and other diseases. Allergy. 2010;65(2):238-44. Epub 2009/10/03.

4. Umasunthar T, Leonardi-Bee J, Hodes M, Turner PJ, Gore C, Habibi P, et al. Incidence of fatal food anaphylaxis in people with food allergy: a systematic review and meta-analysis. Clinical and experimental allergy : journal of the British Society for Allergy and Clinical Immunology. 2013;43(12):1333-41. Epub 2013/10/15.

5. Moher D, Liberati A, Tetzlaff J, Altman DG, Group P. Preferred reporting items for systematic reviews and meta-analyses: the PRISMA statement. Annals of internal medicine. 2009;151(4):264-9, W64. Epub 2009/07/23.

6. GA Wells BS, D O'Connell, J Peterson, V Welch, M Losos, P Tugwell. The Newcastle-Ottawa Scale (NOS) for assessing the quality of nonrandomised studies in meta-analyses.

7. Sampson HA, Munoz-Furlong A, Campbell RL, Adkinson NF, Jr., Bock SA, Branum A, et al. Second symposium on the definition and management of anaphylaxis: summary report--Second National Institute of Allergy and Infectious Disease/Food Allergy and Anaphylaxis Network symposium. The Journal of allergy and clinical immunology. 2006;117(2):391-7. Epub 2006/02/08.

8. Branum AM, Lukacs SL. Food allergy among children in the United States. Pediatrics. 2009;124(6):1549-55.

9. Sicherer SH. Epidemiology of food allergy. Journal of Allergy and Clinical Immunology. 2011;127(3):594-602.

This article is protected by copyright. All rights reserved. 
10. Venter C, Hasan Arshad S, Grundy J, Pereira B, Bernie Clayton C, Voigt K, et al. Time trends in the prevalence of peanut allergy: three cohorts of children from the same geographical location in the UK. Allergy. 2010;65(1):103-8.

11. Boyano-Martinez T, Garcia-Ara C, Pedrosa M, Diaz-Pena JM, Quirce S. Accidental allergic reactions in children allergic to cow's milk proteins. The Journal of allergy and clinical immunology. 2009;123(4):883-8. Epub 2009/02/24.

12. Cianferoni A, Novembre E, Pucci N, Lombardi E, Bernardini R, Vierucci A. Anaphylaxis: a 7-year follow-up survey of 46 children. Ann Allergy Asthma Immunol. 2004;92(4):464-8.

13. Fleischer DM, Perry TT, Atkins D, Wood RA, Burks AW, Jones SM, et al. Allergic reactions to foods in preschool-aged children in a prospective observational food allergy study. Pediatrics. 2012;130(1):e25-32. Epub 2012/06/27.

14. Gold MS, Sainsbury R. First aid anaphylaxis management in children who were prescribed an epinephrine autoinjector device (EpiPen). The Journal of allergy and clinical immunology. 2000;106(1 Pt 1):171-6.

15. Vander Leek TK, Liu AH, Stefanski K, Blacker B, Bock SA. The natural history of peanut allergy in young children and its association with serum peanut-specific $\lg E$. $J$ Pediatr. 2000;137(6):749-55. Epub 2000/12/13.

16. Yu JW, Kagan R, Verreault N, Nicolas N, Joseph L, St. Pierre Y, et al. Accidental ingestions in children with peanut allergy. Journal of Allergy and Clinical Immunology. 2006;118(2):466-72.

This article is protected by copyright. All rights reserved. 
17. Clark AT, Ewan PW. Good prognosis, clinical features, and circumstances of peanut and tree nut reactions in children treated by a specialist allergy center. Journal of Allergy and Clinical Immunology. 2008;122(2):286-9.

18. Sicherer SH, Furlong TJ, Muñoz-Furlong A, Burks AW, Sampson HA. A voluntary registry for peanut and tree nut allergy: Characteristics of the first 5149 registrants. Journal of Allergy and Clinical Immunology. 2001;108(1):128-32.

19. Nha UNL, Ben-Shoshan M, Alizadehfar R, Joseph L, Harada L, Allen M, et al. Inadvertent exposures in children with peanut allergy. Pediatric Allergy and Immunology. 2012;23(2):134-40.

20. Neuman-Sunshine DL, Eckman JA, Keet CA, Matsui EC, Peng RD, Lenehan PJ, et al. The natural history of persistent peanut allergy. Annals of Allergy Asthma \& Immunology. 2012;108(5):326-U141.

21. Bock SA. The incidence of severe adverse reactions to food in Colorado. Journal of Allergy and Clinical Immunology. 1992;90 (4 I):683-5.

22. Bohlke K, Davis RL, DeStefano F, Marcy SM, Braun MM, Thompson RS. Epidemiology of anaphylaxis among children and adolescents enrolled in a health maintenance organization. Journal of Allergy and Clinical Immunology. 2004;113(3):536-42.

23. Braganza SC, Acworth JP, Mckinnon DRL, Peake JE, Brown AFT. Paediatric emergency department anaphylaxis: different patterns from adults. Archives of Disease in Childhood. 2006;91(2):159-63.

24. Decker WW, Campbell RL, Manivannan V, Luke A, St Sauver JL, Weaver A, et al. The etiology and incidence of anaphylaxis in Rochester, Minnesota: a report from the 
Rochester Epidemiology Project. The Journal of allergy and clinical immunology. 2008;122(6):1161-5.

25. Helbling A, Hurni T, Mueller UR, Pichler WJ. Incidence of anaphylaxis with circulatory symptoms: a study over a 3-year period comprising 940000 inhabitants of the Swiss Canton Bern. Clinical \& Experimental Allergy. 2004;34(2):285-90.

26. Iribarren C, Tolstykh IV, Miller MK, Eisner MD. Asthma and the prospective risk of anaphylactic shock and other allergy diagnoses in a large integrated health care delivery system. Annals of Allergy, Asthma \& Immunology. 2010;104(5):371-7.e2.

27. Peng MM, Jick H. A Population-Based Study of the Incidence, Cause, and Severity of Anaphylaxis in the United Kingdom. Arch Intern Med. 2004;164(3):317-9. 28. Ross MP, Ferguson M, Street D, Klontz K, Schroeder T, Luccioli S. Analysis of food-allergic and anaphylactic events in the National Electronic Injury Surveillance System. Journal of Allergy and Clinical Immunology. 2008;121(1):166-71.

29. Yocum MW, Butterfield JH, Klein JS, Volcheck GW, Schroeder DR, Silverstein MD. Epidemiology of anaphylaxis in Olmsted County: A population-based study. Journal of Allergy and Clinical Immunology. 1999;104(2):452-6.

30. Harduar-Morano L, Simon MR, Watkins S, Blackmore C. A population-based epidemiologic study of emergency department visits for anaphylaxis in Florida. Journal of Allergy \& Clinical Immunology. 2011;128(3):594-600.e1.

31. Simons FER CZ, Gold M. Anaphylaxis in children - Real-time reporting from a national network. . Allergy Clin Immunol Int 2004:Supplement 1:242-4.

32. Tejedor Alonso MA, Moro Moro M, Mugica Garcia MV, Esteban Hernandez J, Rosado Ingelmo A, Vila Albelda C, et al. Incidence of anaphylaxis in the city of Alcorcon 
(Spain): a population-based study. Clinical and experimental allergy : journal of the British Society for Allergy and Clinical Immunology. 2012;42(4):578-89. Epub 2012/03/16.

33. Vetander M, Helander D, Flodstrom C, Ostblom E, Alfven T, Ly DH, et al. Anaphylaxis and reactions to foods in children - a population-based case study of emergency department visits. Clinical and Experimental Allergy. 2012;42(4):568-77.

34. Calvani M, Di Lallo D, Polo A, Spinelli A, Zappala D, Zicari AM. Hospitalizations for pediatric anaphylaxis. Int J Immunopathol Pharmacol. 2008;21(4):977-83. Epub 2009/01/16.

35. Colver AF, Nevantaus H, Macdougall CF, Cant AJ. Severe food-allergic reactions in children across the UK and Ireland, 1998-2000. Acta Paediatrica, International Journal of Paediatrics. 2005;94 (6):689-95.

36. Foucard T, Malmheden Yman I. A study on severe food reactions in Sweden - is soy protein an underestimated cause of food anaphylaxis? Allergy. 1999;54(3):261-5.

37. Lin RY, Anderson AS, Shah SN, Nurruzzaman F. Increasing anaphylaxis hospitalizations in the first 2 decades of life: New York State, 1990 -2006. Ann Allergy Asthma Immunol. 2008;101(4):387-93. Epub 2008/10/23.

38. Mulla ZD. Hospitalizations of children and young adults from peanut-induced anaphylaxis in Texas. South Med J. 2011;104(5):322-4. Epub 2011/05/25.

39. Mulla ZD, Simon MR. Hospitalizations for anaphylaxis in Florida: epidemiologic analysis of a population-based dataset. Int Arch Allergy Immunol. 2007;144(2):128-36. Epub 2007/05/31.

This article is protected by copyright. All rights reserved. 
40. Mullins RJ, Clark S, Camargo CA. Socio-economic status, geographic remoteness and childhood food allergy and anaphylaxis in Australia. Clinical \& Experimental Allergy. 2010;40(10):1523-32.

41. Poulos LM, Waters A-M, Correll PK, Loblay RH, Marks GB. Trends in hospitalizations for anaphylaxis, angioedema, and urticaria in Australia, 1993-1994 to 2004-2005. Journal of Allergy and Clinical Immunology. 2007;120(4):878-84.

42. Sheikh A, Alves B. Hospital admissions for acute anaphylaxis: time trend study. BMJ. 2000;320(7247):1441. Epub 2000/05/29.

43. Nocerino R, Cosenza L, Leone L, Di Costanzo M, Buongiovanni A, Passariello A, et al. Increasing hospital admissions for food-induced anaphylaxis in Italian children. Digestive and Liver Disease. 2011;43:S425-S6.

44. Ho MHK, Wong LM, Ling SC, Kwok KL, Lee KP, Hui J, et al. Clinical characteristics and etiologies of severe systemic allergic reaction amongst children admitting to hospital authority paediatric service. Hong Kong Journal of Paediatrics. 2009;14 (4):297.

45. Akeson N, Worth A, Sheikh A. The psychosocial impact of anaphylaxis on young people and their parents. Clinical \& Experimental Allergy. 2007;37(8):1213-20. 46. Lewis SA, Grimshaw KE, Warner JO, Hourihane JO. The promiscuity of immunoglobulin E binding to peanut allergens, as determined by Western blotting, correlates with the severity of clinical symptoms. Clinical and experimental allergy : journal of the British Society for Allergy and Clinical Immunology. 2005;35(6):767-73.

47. Summers CW, Pumphrey RS, Woods CN, McDowell G, Pemberton PW, Arkwright PD. Factors predicting anaphylaxis to peanuts and tree nuts in patients

This article is protected by copyright. All rights reserved. 
referred to a specialist center. Journal of Allergy and Clinical Immunology. 2008;121(3):632-8.e2.

48. Vadas P, Gold M, Perelman B, Liss GM, Lack G, Blyth T, et al. Platelet-activating factor, PAF acetylhydrolase, and severe anaphylaxis. N Engl J Med. 2008;358(1):28-35. 49. Mullins RJ. Anaphylaxis: risk factors for recurrence. Clinical \& Experimental Allergy. 2003;33(8):1033-40.

50. Menikou S, Patel MP, Rose KL, Botto M, Warner JO, Pickering MC, et al. Relationship between complotype and reported severity of systemic allergic reactions to peanut. The Journal of allergy and clinical immunology. 2012;129(5):1398-401 e3. Epub 2012/02/14.

51. Chafen JJS, Newberry SJ, Riedl MA, Bravata DM, Maglione M, Suttorp MJ, et al. Diagnosing and Managing Common Food Allergies: A Systematic Review. JAMA. 2010;303(18):1848-56.

52. Gupta RS, Springston EE, Warrier MR, Smith B, Kumar R, Pongracic J, et al. The prevalence, severity, and distribution of childhood food allergy in the United States. Pediatrics. 2011;128(1):e9-17. Epub 2011/06/22.

53. Sicherer SH, Forman JA, Noone SA. Use assessment of self-administered epinephrine among food-allergic children and pediatricians. Pediatrics. 2000;105(2):359-62.

This article is protected by copyright. All rights reserved. 
Table 1. Characteristics of included studies.

\begin{tabular}{|c|c|c|c|c|c|c|}
\hline Study & Setting & Population & $\begin{array}{l}\text { Case } \\
\text { identification }\end{array}$ & $\begin{array}{l}\text { Anaphyla } \\
\text { xis } \\
\text { definition } \\
\text { consisten } \\
\text { t with } \\
\text { NIAID/FA } \\
\text { AN }\end{array}$ & Analyses & $\begin{array}{l}{ }^{*} \text { Quali } \\
\text { ty } \\
\text { score }\end{array}$ \\
\hline $\begin{array}{l}\text { Boyano- } \\
\text { Martine } \\
\text { z } 2009 \\
(11)\end{array}$ & $\begin{array}{l}\text { Allergy } \\
\text { clinic, } \\
\text { Spain } \\
2009\end{array}$ & $\begin{array}{l}88 \text { children } \\
\text { with } \\
\text { immediate } \\
\text { reaction to } \\
\text { milk < age } 1 \\
\text { year }\end{array}$ & $\begin{array}{l}\text { Questionnaire } \\
\text { about accidental } \\
\text { allergic reactions } \\
\text { in previous } 12 \\
\text { months. }\end{array}$ & Yes & $\begin{array}{l}\text { Self- } \\
\text { reported } \\
\text { anaphyla } \\
\text { xis }\end{array}$ & $2 / 5$ \\
\hline $\begin{array}{l}\text { Clark } \\
2008 \\
(17)\end{array}$ & $\begin{array}{l}\text { Allergy } \\
\text { clinic, UK }\end{array}$ & $\begin{array}{l}785 \text { nut } \\
\text { allergic } \\
\text { children }\end{array}$ & $\begin{array}{l}\text { Prospectively } \\
\text { recorded at } \\
\text { annual/biannual } \\
\text { follow up. }\end{array}$ & Yes & $\begin{array}{l}\text { Self- } \\
\text { reported } \\
\text { anaphyla } \\
\text { xis }\end{array}$ & $2 / 5$ \\
\hline $\begin{array}{l}\text { Yu } \\
2006(16 \\
\text { ) }\end{array}$ & $\begin{array}{l}\text { Allergy } \\
\text { clinic, } \\
\text { Canada } \\
2000- \\
2005\end{array}$ & $\begin{array}{l}252 \text { peanut } \\
\text { allergic } \\
\text { children age } \\
4-17 \text { years }\end{array}$ & $\begin{array}{l}\text { Questionnaire } \\
\text { sent to patients } \\
\text { identified from } \\
\text { allergy clinic } \\
\text { records. }\end{array}$ & Yes & $\begin{array}{l}\text { Self- } \\
\text { reported } \\
\text { anaphyla } \\
\text { xis }\end{array}$ & $1 / 5$ \\
\hline $\begin{array}{l}\text { Cianfer } \\
\text { oni } \\
2004 \\
(12)\end{array}$ & $\begin{array}{l}\text { Allergy } \\
\text { clinic, } \\
\text { Italy } \\
1994- \\
2003\end{array}$ & $\begin{array}{l}46 \text { patients } \\
\text { age } 0-18 \\
\text { with } \\
\text { previous } \\
\text { anaphylaxis }\end{array}$ & $\begin{array}{l}\text { Telephone } \\
\text { survey of } \\
\text { patients } \\
\text { identified from } \\
\text { clinic database. }\end{array}$ & Yes & $\begin{array}{l}\text { Self- } \\
\text { reported } \\
\text { anaphyla } \\
\text { xis }\end{array}$ & $1 / 5$ \\
\hline $\begin{array}{l}\text { †Sicher } \\
\text { er } 2000 \\
(53)\end{array}$ & $\begin{array}{l}\text { National } \\
\text { patient } \\
\text { registry, } \\
\text { US 1997- } \\
2000\end{array}$ & $\begin{array}{l}5149 \\
\text { voluntary } \\
\text { registrants } \\
\text { with nut } \\
\text { allergy }\end{array}$ & $\begin{array}{l}\text { Self reported } \\
\text { reactions } \\
\text { subsequent to } \\
\text { initial reaction. }\end{array}$ & Yes & $\begin{array}{l}\text { Self- } \\
\text { reported } \\
\text { anaphyla } \\
\text { xis }\end{array}$ & $2 / 5$ \\
\hline $\begin{array}{l}\text { Gold } \\
2000 \\
(14)\end{array}$ & $\begin{array}{l}\text { Allergy } \\
\text { clinic, } \\
\text { Australia } \\
1996- \\
1997\end{array}$ & $\begin{array}{l}68 \text { children } \\
\text { with a } \\
\text { history of } \\
\text { anaphylaxis }\end{array}$ & $\begin{array}{l}\text { Telephone } \\
\text { interview of self } \\
\text { reported } \\
\text { symptoms. }\end{array}$ & No & $\begin{array}{l}\text { Self- } \\
\text { reported } \\
\text { anaphyla } \\
\text { xis }\end{array}$ & $2 / 5$ \\
\hline $\begin{array}{l}\text { Vander } \\
\text { Leek } \\
2000 \\
(15)\end{array}$ & $\begin{array}{l}\text { Allergy } \\
\text { clinic, US } \\
2000\end{array}$ & $\begin{array}{l}83 \text { children } \\
\text { with peanut } \\
\text { allergy } \\
\text { diagnosed } \\
<4\end{array}$ & $\begin{array}{l}\text { Annual clinical } \\
\text { review. }\end{array}$ & No & $\begin{array}{l}\text { Self- } \\
\text { reported } \\
\text { anaphyla } \\
\text { xis }\end{array}$ & $3 / 5$ \\
\hline
\end{tabular}

This article is protected by copyright. All rights reserved. 


\begin{tabular}{|c|c|c|c|c|c|c|}
\hline $\begin{array}{l}\text { Nha } \\
2012 \\
(19)\end{array}$ & $\begin{array}{l}\text { Allergy } \\
\text { clinic and } \\
\text { national } \\
\text { survey } \\
\text { combined } \\
\text {, Canada } \\
2004- \\
2009\end{array}$ & $\begin{array}{l}1411 \\
\text { peanut } \\
\text { allergic } \\
\text { children age } \\
0-18 \text { years }\end{array}$ & $\begin{array}{l}\text { Questionnaire } \\
\text { survey of } \\
\text { patients with at } \\
\text { least } 1 \text { year of } \\
\text { follow up data. }\end{array}$ & Yes & $\begin{array}{l}\text { Self- } \\
\text { reported } \\
\text { anaphyla } \\
\text { xis }\end{array}$ & $2 / 5$ \\
\hline $\begin{array}{l}\text { Fleische } \\
\text { r 2012 } \\
(13)\end{array}$ & $\begin{array}{l}\text { Outpatien } \\
\text { t clinics, } \\
\text { USA } \\
\sim 2009\end{array}$ & $\begin{array}{l}512 \text { infants } \\
\text { age } 3-15 \\
\text { months with } \\
\text { milk or egg } \\
\text { allergy }\end{array}$ & $\begin{array}{l}\text { Prospective } \\
\text { questionnaire } \\
\text { survey of } \\
\text { parents }\end{array}$ & No & $\begin{array}{l}\text { Self- } \\
\text { reported } \\
\text { anaphyla } \\
\text { xis }\end{array}$ & $3 / 5$ \\
\hline $\begin{array}{l}\text { Neuma } \\
\text { n- } \\
\text { Sunshin } \\
\text { e 2012 } \\
(20)\end{array}$ & $\begin{array}{l}\text { Tertiary } \\
\text { allergy } \\
\text { clinics, } \\
\text { Baltimore } \\
\text { USA } \\
2008- \\
2009\end{array}$ & $\begin{array}{l}782 \text { children } \\
\text { aged } 0-16 \\
\text { with peanut } \\
\text { allergy }\end{array}$ & $\begin{array}{l}\text { Retrospective } \\
\text { chart review of } \\
\text { clinic records }\end{array}$ & No & $\begin{array}{l}\text { Self- } \\
\text { reported } \\
\text { anaphyla } \\
\text { xis }\end{array}$ & $2 / 5$ \\
\hline $\begin{array}{l}\text { Harduar } \\
\text {-Morano } \\
2011 \\
(30)\end{array}$ & $\begin{array}{l}\text { Florida } \\
\text { US, } \\
2005- \\
2006\end{array}$ & $\begin{array}{l}\text { Non-federal } \\
\text { ED } \\
\text { attendances } \\
\text {, aged } 0-17\end{array}$ & $\begin{array}{l}\text { Healthcare } \\
\text { records: ICD-9 } \\
\text { codes } 995.6- \\
995.69,995.0, \\
\text { or validated ICD- } \\
9 \text { based } \\
\text { algorithm [35] }\end{array}$ & Yes & $\begin{array}{l}\text { Medically } \\
\text { coded } \\
\text { anaphyla } \\
\text { xis }\end{array}$ & $4 / 5$ \\
\hline $\begin{array}{l}\text { †lribarre } \\
\text { n 2010 } \\
\text { (26) }\end{array}$ & $\begin{array}{l}\text { California } \\
\text { US, } \\
1996- \\
2006\end{array}$ & $\begin{array}{l}\mathrm{HMO} \\
\text { database }\end{array}$ & $\begin{array}{l}\text { Healthcare } \\
\text { records: ICD-9 } \\
\text { codes } 995.0, \\
995.6,999.4 \\
\text { Insect } \\
\text { sting/drug/anest } \\
\text { hetic excluded }\end{array}$ & Yes & $\begin{array}{l}\text { Medically } \\
\text { coded } \\
\text { anaphyla } \\
\text { xis }\end{array}$ & $4 / 5$ \\
\hline
\end{tabular}

This article is protected by copyright. All rights reserved. 


\begin{tabular}{|c|c|c|c|c|c|c|}
\hline $\begin{array}{l}\text { Simons } \\
2004 \\
(31)\end{array}$ & $\begin{array}{l}\text { Canada, } \\
2000- \\
2001\end{array}$ & $\begin{array}{l}\text { Canadian } \\
\text { population } \\
\text { aged } 0-17\end{array}$ & $\begin{array}{l}\text { Survey of } \\
\text { pediatricians - } \\
\text { cases had } \\
\text { severe allergic } \\
\text { reaction with } \\
\text { sudden onset } \\
\text { involving } 1 \text { or } \\
\text { more body } \\
\text { systems with } \\
\text { typical allergy } \\
\text { symptoms, } \\
\text { resolving within } \\
24 \text { hours. }\end{array}$ & No & $\begin{array}{l}\text { Medically } \\
\text { coded } \\
\text { anaphyla } \\
\text { xis }\end{array}$ & $2 / 5$ \\
\hline $\begin{array}{l}\text { Ross } \\
2008 \\
(28)\end{array}$ & US 2003 & $\begin{array}{l}\text { Representat } \\
\text { ive sample } \\
\text { of ED } \\
\text { attendances }\end{array}$ & $\begin{array}{l}\text { Healthcare } \\
\text { records - either } \\
\text { 'anaphylaxis' } \\
\text { mentioned in ED } \\
\text { notes, or } \\
\text { anaphylaxis } \\
\text { symposium } \\
\text { definition [9] }\end{array}$ & Yes & $\begin{array}{l}\text { Medically } \\
\text { coded } \\
\text { anaphyla } \\
\text { xis }\end{array}$ & $4 / 5$ \\
\hline $\begin{array}{l}\text { Decker } \\
2008 \\
(24)\end{array}$ & $\begin{array}{l}\text { Olmsted } \\
\text { County, } \\
\text { US , } \\
1990- \\
2000\end{array}$ & $\begin{array}{l}\text { Olmsted } \\
\text { residents }\end{array}$ & $\begin{array}{l}\text { Healthcare } \\
\text { records - two } \\
\text { system } \\
\text { involvement or } \\
\text { hypotension or } \\
\text { laryngeal edema }\end{array}$ & No & $\begin{array}{l}\text { Medically } \\
\text { coded } \\
\text { anaphyla } \\
\text { xis }\end{array}$ & $4 / 5$ \\
\hline $\begin{array}{l}\text { Braganz } \\
\text { a 2006 } \\
\text { (23) }\end{array}$ & $\begin{array}{l}\text { Brisbane, } \\
\text { Australia } \\
1998- \\
2001\end{array}$ & $\begin{array}{l}\text { ED } \\
\text { attendances } \\
\text { age } 0-16\end{array}$ & $\begin{array}{l}\text { Review of all } \\
\text { case notes of } \\
\text { children with } \\
\text { ICD-9 discharge } \\
\text { code of allergy, } \\
\text { allergic reaction, } \\
\text { anaphylactic } \\
\text { shock/reaction, } \\
\text { angioedema and } \\
\text { urticaria, using } \\
\text { ASCIA definition } \\
\text { of anaphylaxis }\end{array}$ & Yes & $\begin{array}{l}\text { Medically } \\
\text { coded } \\
\text { anaphyla } \\
\text { xis }\end{array}$ & $4 / 5$ \\
\hline
\end{tabular}

This article is protected by copyright. All rights reserved. 


\begin{tabular}{|c|c|c|c|c|c|c|}
\hline $\begin{array}{l}\text { Peng } \\
2004 \\
(27)\end{array}$ & $\begin{array}{l}\text { UK } \\
\text { primary } \\
\text { care } \\
\text { database, } \\
1994- \\
1999\end{array}$ & $\begin{array}{l}\text { UK } \\
\text { population }\end{array}$ & $\begin{array}{l}\text { Healthcare } \\
\text { record s - Oxford } \\
\text { Medical } \\
\text { information } \\
\text { system Codes } \\
\text { 9779AK, } \\
\text { 9779AR, } \\
\text { 9894HA, } \\
\text { 9894HB, } \\
\text { 9894HN, } \\
\text { 9899AN, 9994, } \\
\text { 9994CC, } \\
\text { 9994MN, } \\
\text { 9994RM, or free } \\
\text { text entry of } \\
\text { Anaphylaxis }\end{array}$ & No & $\begin{array}{l}\text { Medically } \\
\text { coded } \\
\text { anaphyla } \\
\text { xis }\end{array}$ & $4 / 5$ \\
\hline $\begin{array}{l}\text { Helbling } \\
2004 \\
(25)\end{array}$ & $\begin{array}{l}\text { Bern, } \\
\text { Sweden } \\
1996- \\
1998\end{array}$ & $\begin{array}{l}\text { Population } \\
\text { of Bern } \\
\text { Canton }\end{array}$ & $\begin{array}{l}\text { Healthcare } \\
\text { records and } \\
\text { survey of } \\
\text { specialists: } \\
\text { Severe systemic } \\
\text { anaphylaxis with } \\
\text { hypotension, } \\
\text { unconsciousnes } \\
\text { s, shock } \\
\text { identified using } \\
\text { ICD-10 codes } \\
\text { D69.0, T63.4, } \\
\text { T78.0, T78.1, } \\
\text { T78.2, T78.3, } \\
\text { T88.2, T88.6, } \\
\text { T88.7, X23 }\end{array}$ & No & $\begin{array}{l}\text { Medically } \\
\text { coded } \\
\text { anaphyla } \\
\text { xis }\end{array}$ & $4 / 5$ \\
\hline $\begin{array}{l}\text { Bohlke } \\
2004 \\
(22)\end{array}$ & $\begin{array}{l}\text { Washingt } \\
\text { on US } \\
1991- \\
1997\end{array}$ & $\begin{array}{l}\mathrm{HMO} \\
\text { database } \\
\text { age } 0-17\end{array}$ & $\begin{array}{l}\text { Healthcare } \\
\text { records review } \\
\text { after search by } \\
\text { ICD code. Two } \\
\text { system } \\
\text { involvement or } 1 \\
\text { system + onset } \\
\leq 4 \mathrm{~h} \text { after } \\
\text { exposure + } \\
\text { treated with a } \\
\text { relevant } \\
\text { medication }\end{array}$ & No & $\begin{array}{l}\text { Medically } \\
\text { coded } \\
\text { anaphyla } \\
\text { xis }\end{array}$ & $4 / 5$ \\
\hline
\end{tabular}

This article is protected by copyright. All rights reserved. 


\begin{tabular}{|c|c|c|c|c|c|c|}
\hline $\begin{array}{l}\text { Bock } \\
1992 \\
(21)\end{array}$ & $\begin{array}{l}\text { Colorado } \\
\text { USA } \\
1990- \\
1991\end{array}$ & $\begin{array}{l}\text { ED } \\
\text { attendances }\end{array}$ & $\begin{array}{l}\text { Emergency } \\
\text { department } \\
\text { survey - } \\
\text { identified cases } \\
\text { of probable food } \\
\text { anaphylaxis } \\
\text { involving } \\
\text { respiratory } \\
\text { and/or } \\
\text { cardiovascular } \\
\text { symptoms, or } \\
\text { fatal food } \\
\text { anaphylaxis }\end{array}$ & Yes & $\begin{array}{l}\text { Medically } \\
\text { coded } \\
\text { anaphyla } \\
\text { xis }\end{array}$ & $3 / 5$ \\
\hline $\begin{array}{l}\text { Yocum } \\
1999 \\
(29)\end{array}$ & $\begin{array}{l}\text { Olmsted } \\
\text { County, } \\
\text { US 1983- } \\
1987\end{array}$ & $\begin{array}{l}\text { Olmsted } \\
\text { residents }\end{array}$ & $\begin{array}{l}\text { Healthcare } \\
\text { records - two } \\
\text { system } \\
\text { involvement, } \\
\text { hypotension or } \\
\text { laryngeal edema }\end{array}$ & No & $\begin{array}{l}\text { Medically } \\
\text { coded } \\
\text { anaphyla } \\
\text { xis }\end{array}$ & $4 / 5$ \\
\hline $\begin{array}{l}\text { Tejedor } \\
2011 \\
(32)\end{array}$ & $\begin{array}{l}\text { Alcorcon, } \\
\text { Spain } \\
2004- \\
2005\end{array}$ & $\begin{array}{l}\text { Primary } \\
\text { care and } \\
\text { hospital } \\
\text { records }\end{array}$ & $\begin{array}{l}\text { Healthcare } \\
\text { records review: } \\
\text { NIAID/FAAN } \\
\text { symposium } \\
\text { definition }\end{array}$ & Yes & $\begin{array}{l}\text { Medically } \\
\text { coded } \\
\text { anaphyla } \\
\text { xis }\end{array}$ & $4 / 5$ \\
\hline $\begin{array}{l}\text { Vetande } \\
\text { r } 2012 \\
\text { (33) }\end{array}$ & $\begin{array}{l}\text { Stockhol } \\
\text { m, } \\
\text { Sweden } \\
2007\end{array}$ & $\begin{array}{l}\text { ED } \\
\text { attendances } \\
\text { aged } 0-18\end{array}$ & $\begin{array}{l}\text { Healthcare } \\
\text { records review } \\
\text { after search } \\
\text { based on ICD- } \\
10 \text { codes - two } \\
\text { system } \\
\text { involvement } \\
\text { after exposure to } \\
\text { a likely allergen, } \\
\text { or } \\
\text { hypotension } \\
\text { alone after } \\
\text { exposure to } \\
\text { known allergen } \\
\text { for the patient }\end{array}$ & No & $\begin{array}{l}\text { Medically } \\
\text { coded } \\
\text { anaphyla } \\
\text { xis }\end{array}$ & $3 / 5$ \\
\hline $\begin{array}{l}\text { Lin } \\
2008 \\
(37)\end{array}$ & $\begin{array}{l}\text { New York } \\
\text { State US } \\
1990- \\
2006\end{array}$ & $\begin{array}{l}\text { NY state } \\
\text { population } \\
\text { age } 0-19\end{array}$ & $\begin{array}{l}\text { Statewide } \\
\text { hospitalization } \\
\text { database: ICD-9 } \\
\text { code } 995.6\end{array}$ & Yes & $\begin{array}{l}\text { Anaphyla } \\
\text { xis } \\
\text { admissio } \\
n\end{array}$ & $4 / 5$ \\
\hline
\end{tabular}

This article is protected by copyright. All rights reserved. 


\begin{tabular}{|c|c|c|c|c|c|c|}
\hline $\begin{array}{l}\text { Poulos } \\
2007 \\
(41)\end{array}$ & $\begin{array}{l}\text { Australia } \\
1993- \\
2005\end{array}$ & $\begin{array}{l}\text { Australian } \\
\text { population }\end{array}$ & $\begin{array}{l}\text { National } \\
\text { hospitalization } \\
\text { database: ICD-9 } \\
\text { 995.0, 995.6, } \\
\text { 999.4, and ICD } \\
\text { 10 T78.0, 78.2, } \\
\text { 80.5, 88.6 }\end{array}$ & Yes & $\begin{array}{l}\text { Anaphyla } \\
\text { xis } \\
\text { admissio } \\
n\end{array}$ & $4 / 5$ \\
\hline $\begin{array}{l}\text { Mulla } \\
2007 \\
(39)\end{array}$ & $\begin{array}{l}\text { Florida, } \\
\text { US } 2001\end{array}$ & $\begin{array}{l}\text { Florida } \\
\text { population }\end{array}$ & $\begin{array}{l}\text { Statewide } \\
\text { hospitalization } \\
\text { database: ICD- } \\
\text { 9CM codes } \\
\text { 995.0/995-6- } \\
995.69 \\
995.4 / 995.0 \\
(\text { E930.0-931.0) }\end{array}$ & Yes & $\begin{array}{l}\text { Anaphyla } \\
\text { xis } \\
\text { admissio } \\
n\end{array}$ & $4 / 5$ \\
\hline $\begin{array}{l}\text { Colver } \\
2005 \\
(35)\end{array}$ & $\begin{array}{l}\text { United } \\
\text { Kingdom } \\
1998- \\
2000\end{array}$ & $\begin{array}{l}\text { UK } \\
\text { population } \\
\text { aged } 0-15\end{array}$ & $\begin{array}{l}\text { Survey of } \\
\text { pediatricians: } \\
\text { cardiorespiratory } \\
\text { arrest, inotropes, } \\
>20 \mathrm{ml} / \mathrm{kg} \text { fluid } \\
\text { resuscitation, }>1 \\
\text { dose } \\
\text { epinephrine, or } \\
>1 \text { dose } \\
\text { nebulized } \\
\text { bronchodilator }\end{array}$ & No & $\begin{array}{l}\text { Anaphyla } \\
\text { xis } \\
\text { admissio } \\
n\end{array}$ & $3 / 5$ \\
\hline $\begin{array}{l}\text { Sheikh } \\
2000 \\
(42)\end{array}$ & $\begin{array}{l}\text { England } \\
1991- \\
1995\end{array}$ & $\begin{array}{l}\text { Total } \\
\text { England } \\
\text { population }\end{array}$ & $\begin{array}{l}\text { Hospital episode } \\
\text { statistics } \\
\text { searched for } \\
\text { ICD codes } \\
995.0 / 999.4\end{array}$ & Yes & $\begin{array}{l}\text { Anaphyla } \\
\text { xis } \\
\text { admissio } \\
n\end{array}$ & $4 / 5$ \\
\hline $\begin{array}{l}\text { Mulla } \\
2011 \\
(38)\end{array}$ & $\begin{array}{l}\text { Texas, } \\
\text { US 2004- } \\
2007\end{array}$ & $\begin{array}{l}\text { Texas } \\
\text { population } \\
\text { aged } 0-24\end{array}$ & $\begin{array}{l}\text { Statewide } \\
\text { hospitalization } \\
\text { database: } \\
\text { discharge } \\
\text { diagnosis of } \\
\text { anaphylactic } \\
\text { shock due to } \\
\text { peanut, ICD-9 } \\
\text { code } 995.61\end{array}$ & Yes & $\begin{array}{l}\text { Anaphyla } \\
\text { xis } \\
\text { admissio } \\
n\end{array}$ & $4 / 5$ \\
\hline $\begin{array}{l}\text { Mullins } \\
2010 \\
(40)\end{array}$ & $\begin{array}{l}\text { Australia } \\
2002- \\
2007\end{array}$ & $\begin{array}{l}\text { Australia } \\
\text { population }\end{array}$ & $\begin{array}{l}\text { National } \\
\text { hospitalization } \\
\text { database: ICD- } \\
10 \text { code T78 }\end{array}$ & Yes & $\begin{array}{l}\text { Anaphyla } \\
\text { xis } \\
\text { admissio } \\
n\end{array}$ & $4 / 5$ \\
\hline
\end{tabular}

This article is protected by copyright. All rights reserved. 


\begin{tabular}{|c|c|c|c|c|c|c|}
\hline $\begin{array}{l}\text { Foucard } \\
1999 \\
(36)\end{array}$ & $\begin{array}{l}\text { Sweden } \\
1993- \\
1996\end{array}$ & $\begin{array}{l}\text { Swedish } \\
\text { population }\end{array}$ & $\begin{array}{l}\text { Survey of } \\
\text { physicians, with } \\
\text { case notes } \\
\text { scrutinized by a } \\
\text { single } \\
\text { investigator }\end{array}$ & No & $\begin{array}{l}\text { Anaphyla } \\
\text { xis } \\
\text { admissio } \\
n\end{array}$ & $1 / 5$ \\
\hline $\begin{array}{l}\text { Calvani } \\
2008 \\
(34)\end{array}$ & $\begin{array}{l}\text { Lazio, } \\
\text { Italy } \\
2000- \\
2003\end{array}$ & $\begin{array}{l}\text { Lazio } \\
\text { population } \\
\text { aged } 0-17\end{array}$ & $\begin{array}{l}\text { Hospital and } \\
\text { emergency } \\
\text { department } \\
\text { information } \\
\text { system: ICD } \\
\text { codes } 995.0 \text {, } \\
995.6,995.4, \\
999.4 \text { for } \\
\text { admissions; ICD } \\
\text { codes 708.0, } \\
989.5,995.0 \text {, } \\
995.2,995.3, \\
995.4,995.6, \\
999.4 \text { for } \\
\text { fatalities. }\end{array}$ & Yes & $\begin{array}{l}\text { Anaphyla } \\
\text { xis } \\
\text { admissio } \\
n\end{array}$ & $4 / 5$ \\
\hline $\begin{array}{l}\text { Nocerin } \\
0 \\
2011(43 \\
)\end{array}$ & $\begin{array}{l}\text { Italy, } \\
2001- \\
2005\end{array}$ & $\begin{array}{l}\text { Italy } \\
\text { population } \\
\text { aged } 0-14\end{array}$ & $\begin{array}{l}\text { National hospital } \\
\text { discharge } \\
\text { database: ICD-9 } \\
\text { codes: } 99560 \text {, } \\
\text { 99561, 99562, } \\
\text { 99563, 99564, } \\
99565,99567, \\
\text { 99568, 99569. }\end{array}$ & Yes & $\begin{array}{l}\text { Anaphyla } \\
\text { xis } \\
\text { admissio } \\
n\end{array}$ & $4 / 5$ \\
\hline $\begin{array}{l}\text { Ho } \\
2009 \\
(44)\end{array}$ & $\begin{array}{l}\text { Hong } \\
\text { Kong } \\
2006- \\
2007\end{array}$ & $\begin{array}{l}\text { Hong Kong } \\
\text { population } \\
\text { aged } 0-18\end{array}$ & $\begin{array}{l}\text { Hospital } \\
\text { discharge } \\
\text { database: ICD-9 } \\
\text { codes 995.0, } \\
995.1,995.6\end{array}$ & Yes & $\begin{array}{l}\text { Anaphyla } \\
\text { xis } \\
\text { admissio } \\
n\end{array}$ & $3 / 5$ \\
\hline
\end{tabular}

${ }^{*}$ Quality assessment based on a modified Newcastle-Ottawa scale for Cohort Studies

[8]

† Original data kindly provided by study authors 
Table 2. Food anaphylaxis incidence rates for food allergic people - calculated using different estimates for food allergy prevalence.

\begin{tabular}{|c|c|c|}
\hline & Estimated food allergy prevalence & $\begin{array}{l}\text { Event rate - mean } \\
(95 \% \mathrm{Cl})\end{array}$ \\
\hline \multirow{9}{*}{$\begin{array}{l}\text { Medically coded food } \\
\text { anaphylaxis } \\
\text { (events per } 100 \text { person years) }\end{array}$} & All ages: $2 \%$ & $0.21 \quad(0.08,0.53)$ \\
\hline & All ages: $4 \%$ & $0.11(0.04,0.26)$ \\
\hline & All ages: $6 \%$ & $0.07 \quad(0.03,0.18)$ \\
\hline & Age $0-19: 2 \%$ & $0.39(0.18,0.84)$ \\
\hline & Age 0-19: $3.9 \%$ & $0.20 \quad(0.09,0.43)$ \\
\hline & Age 0-19: $10.4 \%$ & $0.08 \quad(0.03,0.16)$ \\
\hline & Age $0-4: 2 \%$ & $0.72(0.02,33.29)$ \\
\hline & Age $0-4: 3.9 \%$ & $0.37(0.01,17.07)$ \\
\hline & Age 0-4: $10.4 \%$ & $0.14(0.00,6.40)$ \\
\hline Hospital admissions for food & All ages: $2 \%$ & $0.14(0.02,0.10)$ \\
\hline anaphylaxis & All ages: $4 \%$ & $0.07(0.01,0.50)$ \\
\hline (events per 1000 person & All ages: $6 \%$ & $0.05(0.01,0.03)$ \\
\hline years) & Age $0-19: 2 \%$ & $0.39(0.20,0.84)$ \\
\hline & Age 0-19: 3.9\% & $0.20(0.10,0.43)$ \\
\hline & Age 0-19: $10.4 \%$ & $0.08(0.04,0.16)$ \\
\hline & Age $0-4: 2 \%$ & $0.98(0.51,1.81)$ \\
\hline & Age $0-4: 3.9 \%$ & $0.50(0.26,0.93)$ \\
\hline & Age 0-4: 10.4\% & $0.19(0.10,0.35)$ \\
\hline
\end{tabular}

Estimated prevalence rates are taken from the meta-analysis of Rona et al. (2), for symptoms of food allergy and a positive allergy test, or for some estimates from more recent studies $(1,8)$.

This article is protected by copyright. All rights reserved. 
Table 3. Summary of estimated food anaphylaxis rates for food allergic people.

\begin{tabular}{|c|c|c|}
\hline Anaphylaxis definition & Age group & Estimated annual incidence rate \\
\hline \multirow[t]{2}{*}{ Self-reported food anaphylaxis } & All ages & $\begin{array}{l}\text { Less than } 1 \text { episode every } 10 \text { person } \\
\text { years }\end{array}$ \\
\hline & Aged $0-19$ * & $\begin{array}{l}\text { Less than } 1 \text { episode every } 10 \text { person } \\
\text { years }\end{array}$ \\
\hline \multirow[t]{3}{*}{$\begin{array}{l}\text { Medically coded food } \\
\text { anaphylaxis }\end{array}$} & All ages & $\begin{array}{l}\text { Less than } 1 \text { episode every } 300 \text { person } \\
\text { years }\end{array}$ \\
\hline & Aged 0-19 & $\begin{array}{l}\text { Less than } 1 \text { episode every } 250 \text { person } \\
\text { years }\end{array}$ \\
\hline & Aged 0-4 & $\begin{array}{l}\text { Less than } 1 \text { episode every } 5 \text { person } \\
\text { years }\end{array}$ \\
\hline \multirow[t]{3}{*}{$\begin{array}{l}\text { Hospital admissions for food } \\
\text { anaphylaxis }\end{array}$} & All ages & $\begin{array}{l}\text { Less than } 1 \text { episode every } 1000 \\
\text { person years }\end{array}$ \\
\hline & Aged $0-19$ & $\begin{array}{l}\text { Less than } 1 \text { episode every } 2000 \\
\text { person years }\end{array}$ \\
\hline & Aged 0-4 & $\begin{array}{l}\text { Less than } 1 \text { episode every } 1000 \\
\text { person years }\end{array}$ \\
\hline
\end{tabular}

* Data are from follow up studies of food allergic patients seen in allergy clinics. One small study found a higher rate of anaphylaxis (1 episode every 1.7 years (14)).

This article is protected by copyright. All rights reserved. 


\section{Figure Legends}

Figure 1. PRISMA flow chart showing results of literature search.

Figure 2. Estimated rate of medically coded food anaphylaxis (A), or hospital admission for food anaphylaxis (B) for a food allergic person, expressed as incidence rate per 100 person years $(A)$ or per 1000 person years $(B)$.

Figure 3. Estimated rate of self-reported (A) or medically coded (B) food anaphylaxis, or hospital admission for food anaphylaxis (C) for a food allergic person aged 0-19, expressed as incidence rate per 100 person years $(A, B)$ or per 1000 person years $(C)$. Figure 4. Estimated rate of medically coded (A) food anaphylaxis, or hospital admission for food anaphylaxis (B) for a food allergic person aged 0-4, expressed as incidence rate per 100 person years $(A)$ or per 1000 person years $(B)$.

Figure 5. Estimated rate of self-reported (A) or medically coded (B) peanut anaphylaxis, or hospital admission for peanut anaphylaxis (C) for a peanut allergic person, expressed as incidence rate per 100 person years (A, B) or per 1000 person years (C). Figure E1. Funnel plot to assess risk of publication bias in analysis of self-reported food anaphylaxis incidence rate at age 0-19.

Figure E2. Estimated risk of food anaphylaxis for a food allergic person (A) or food allergic person aged 0-19 (B), compared with other general population risks. Continuous bar represents mean with $95 \%$ confidence interval; dotted bar is the range of point estimates from individual studies. Where reference risks vary markedly between European and United States populations, they are stated separately. Otherwise reference risks are for a United States population.

This article is protected by copyright. All rights reserved. 
Figure 1

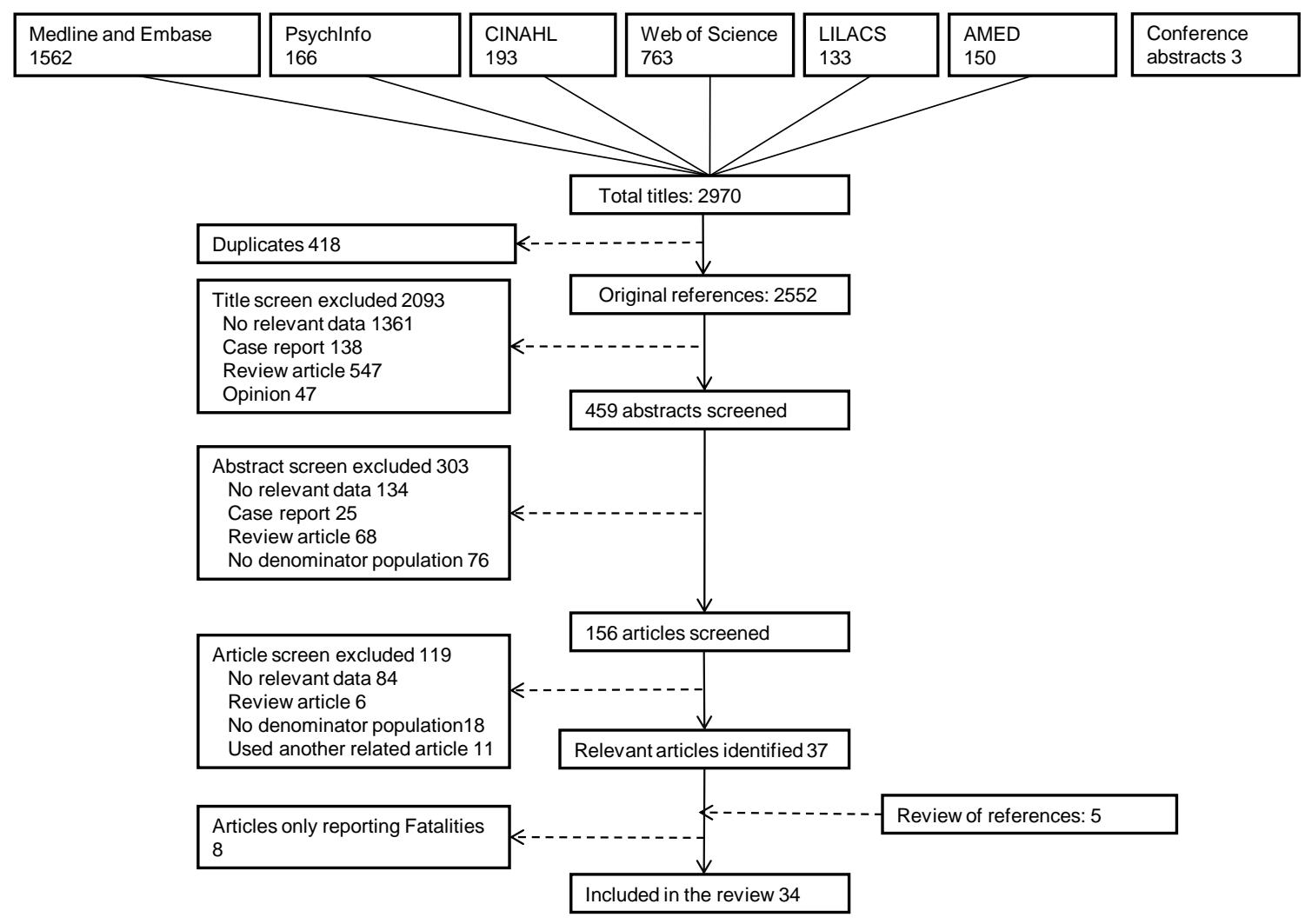



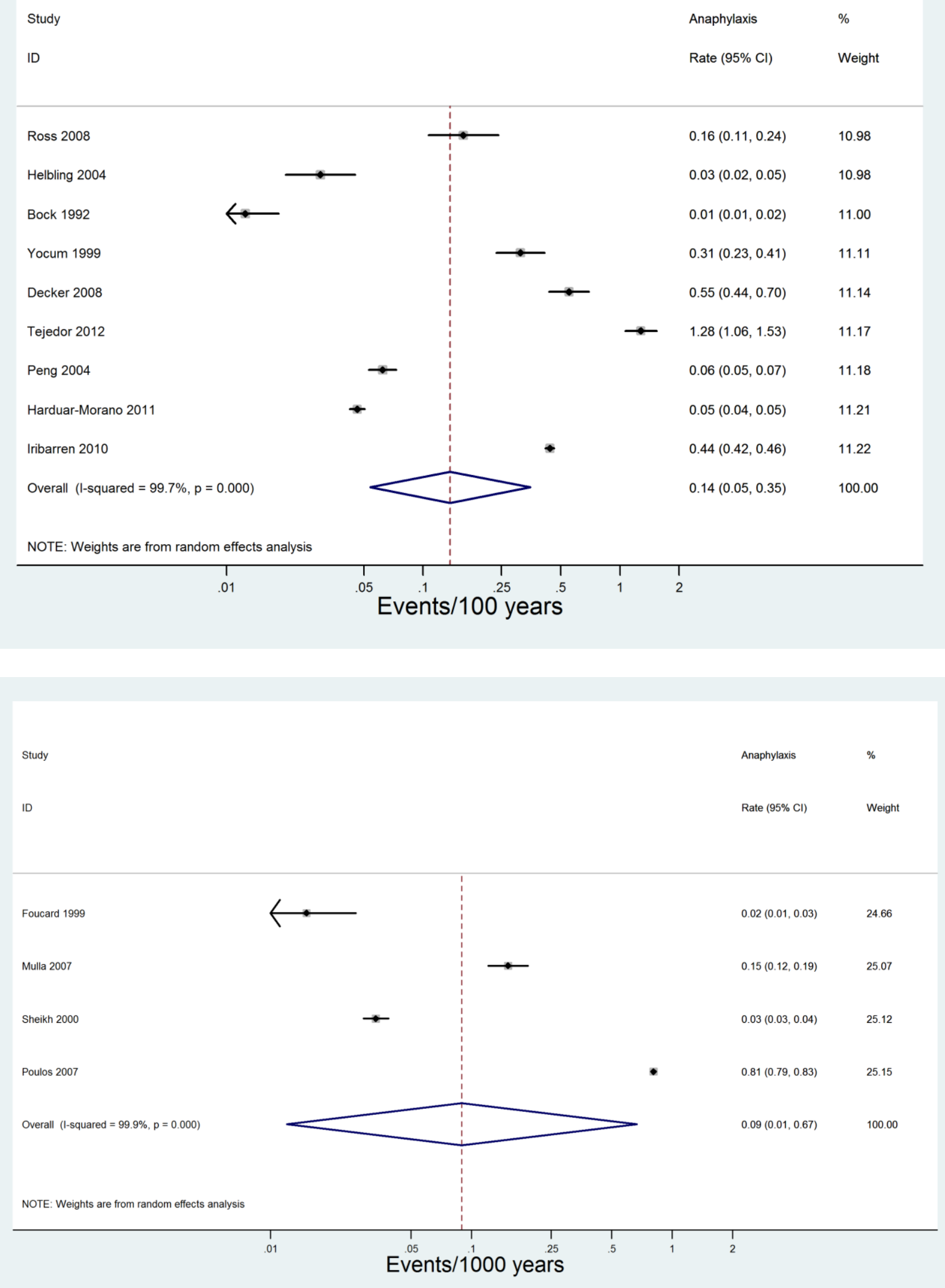

This article is protected by copyright. All rights reserved. 

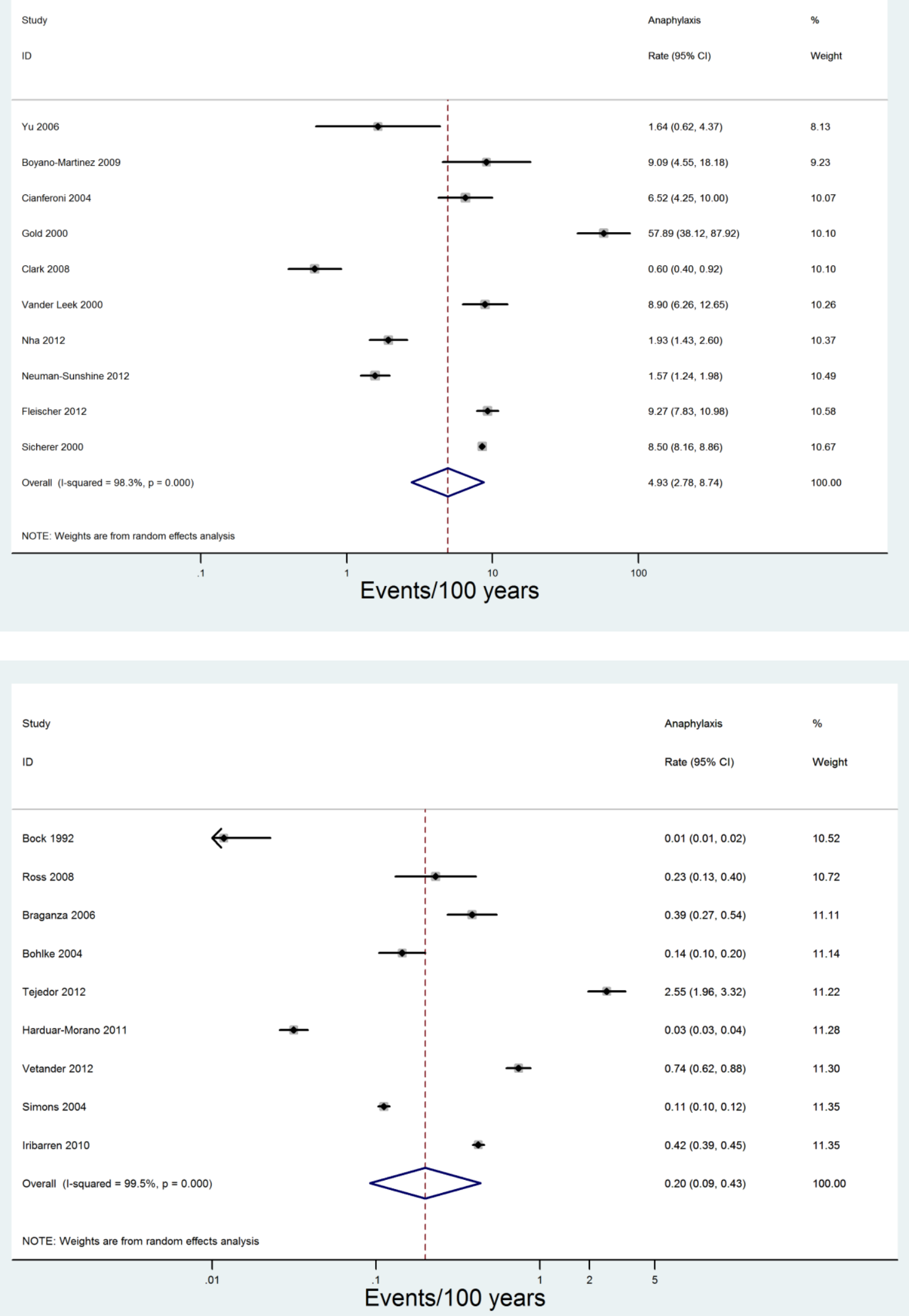

This article is protected by copyright. All rights reserved. 

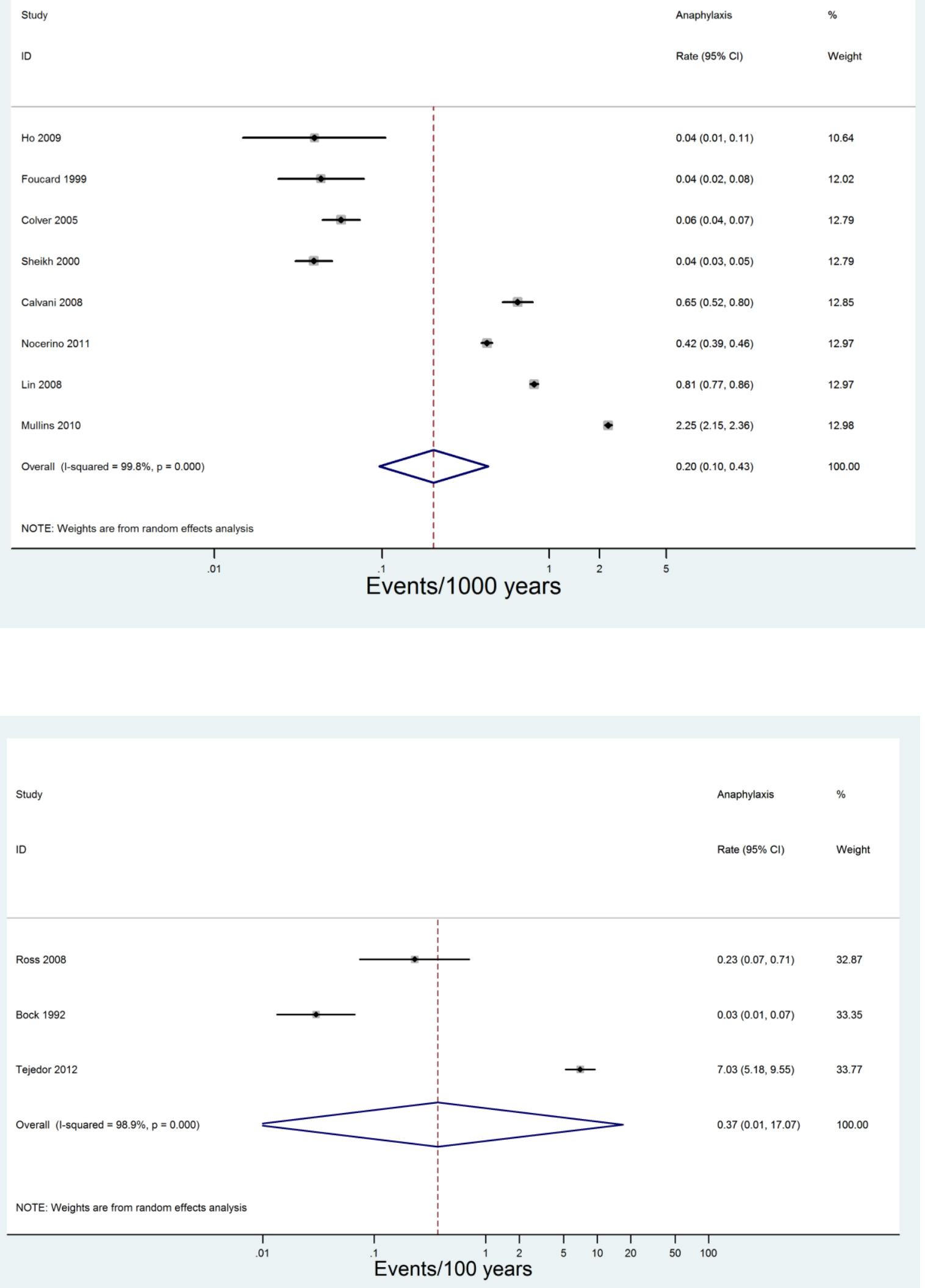

This article is protected by copyright. All rights reserved. 


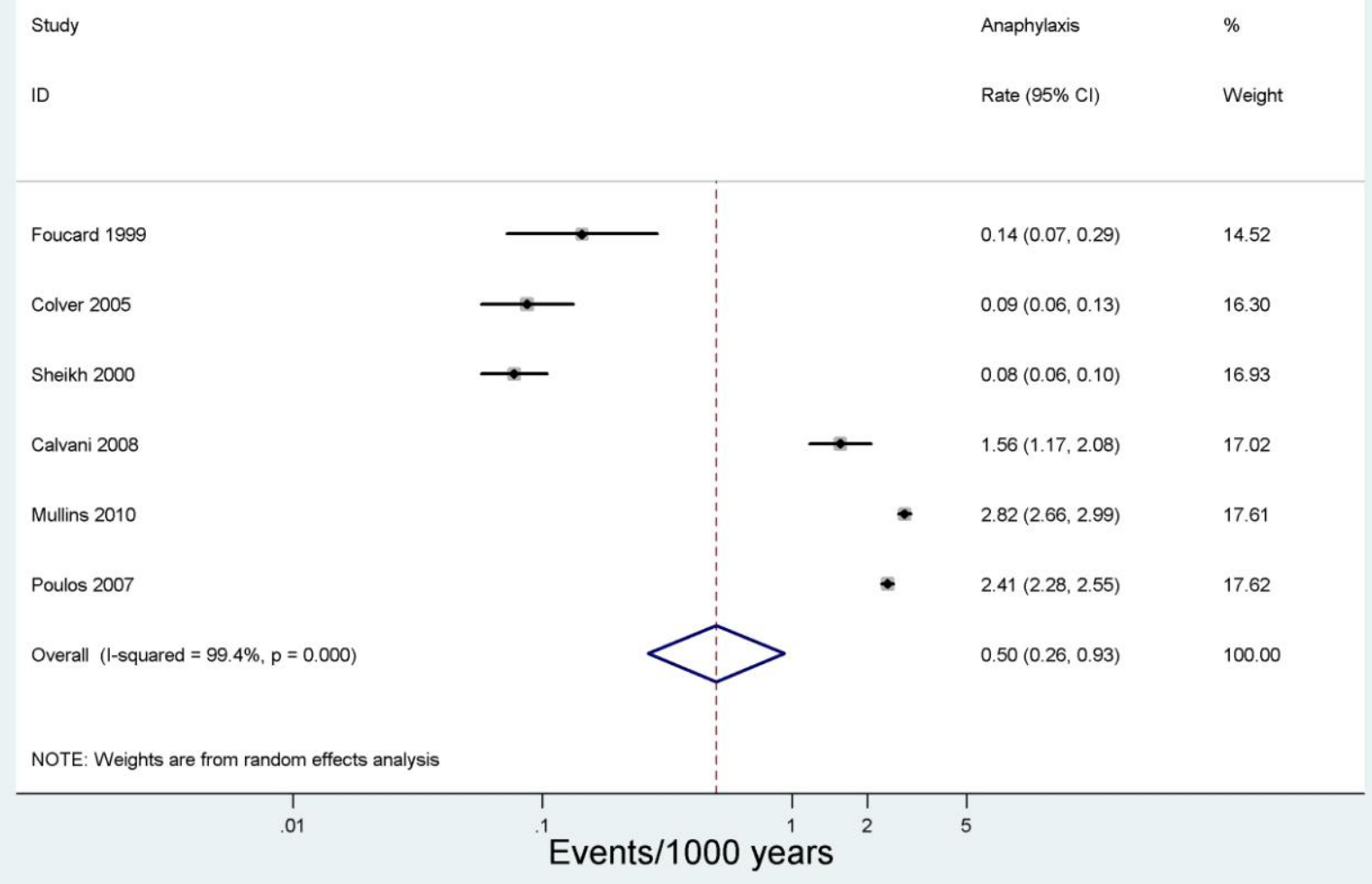

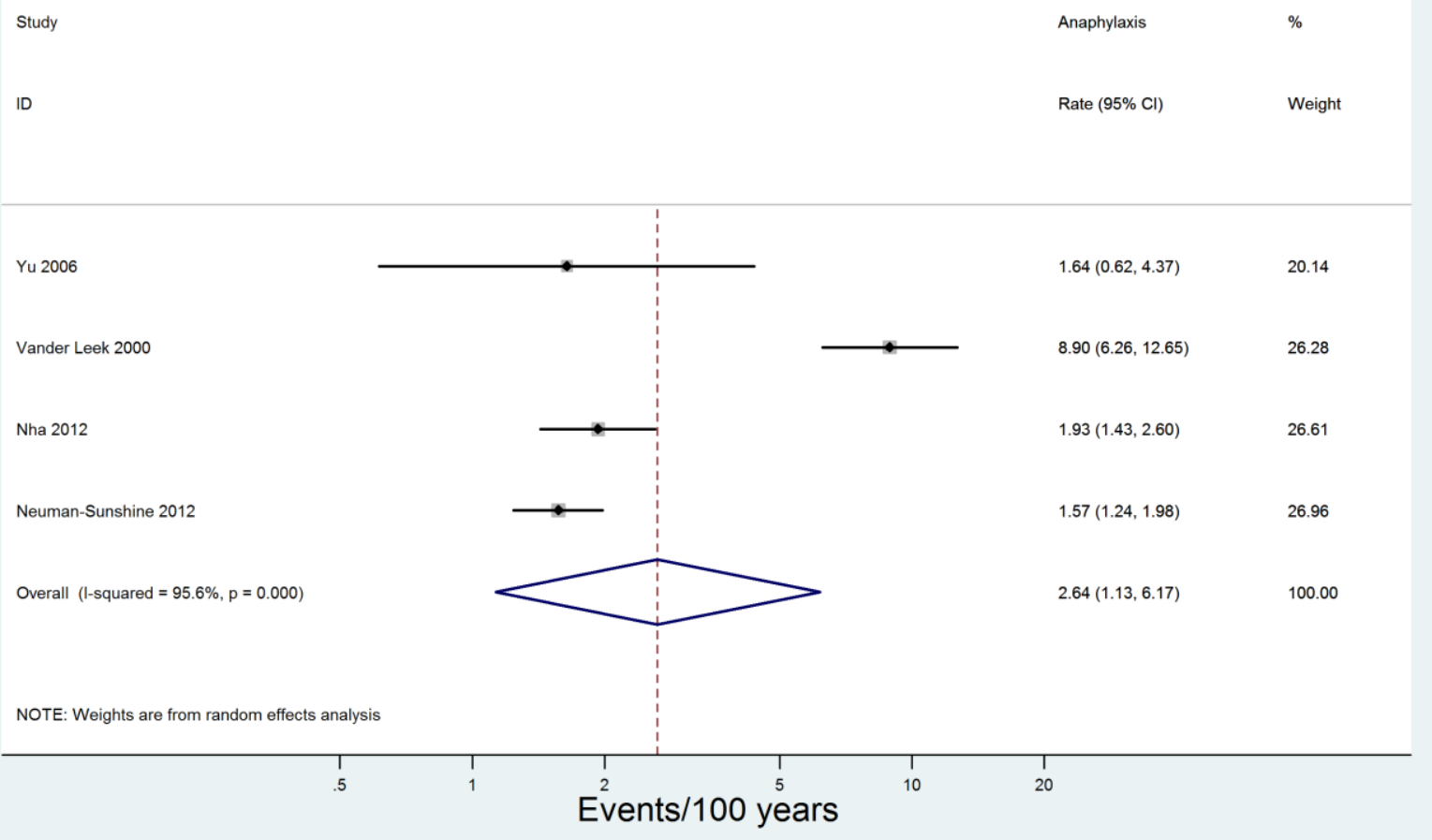



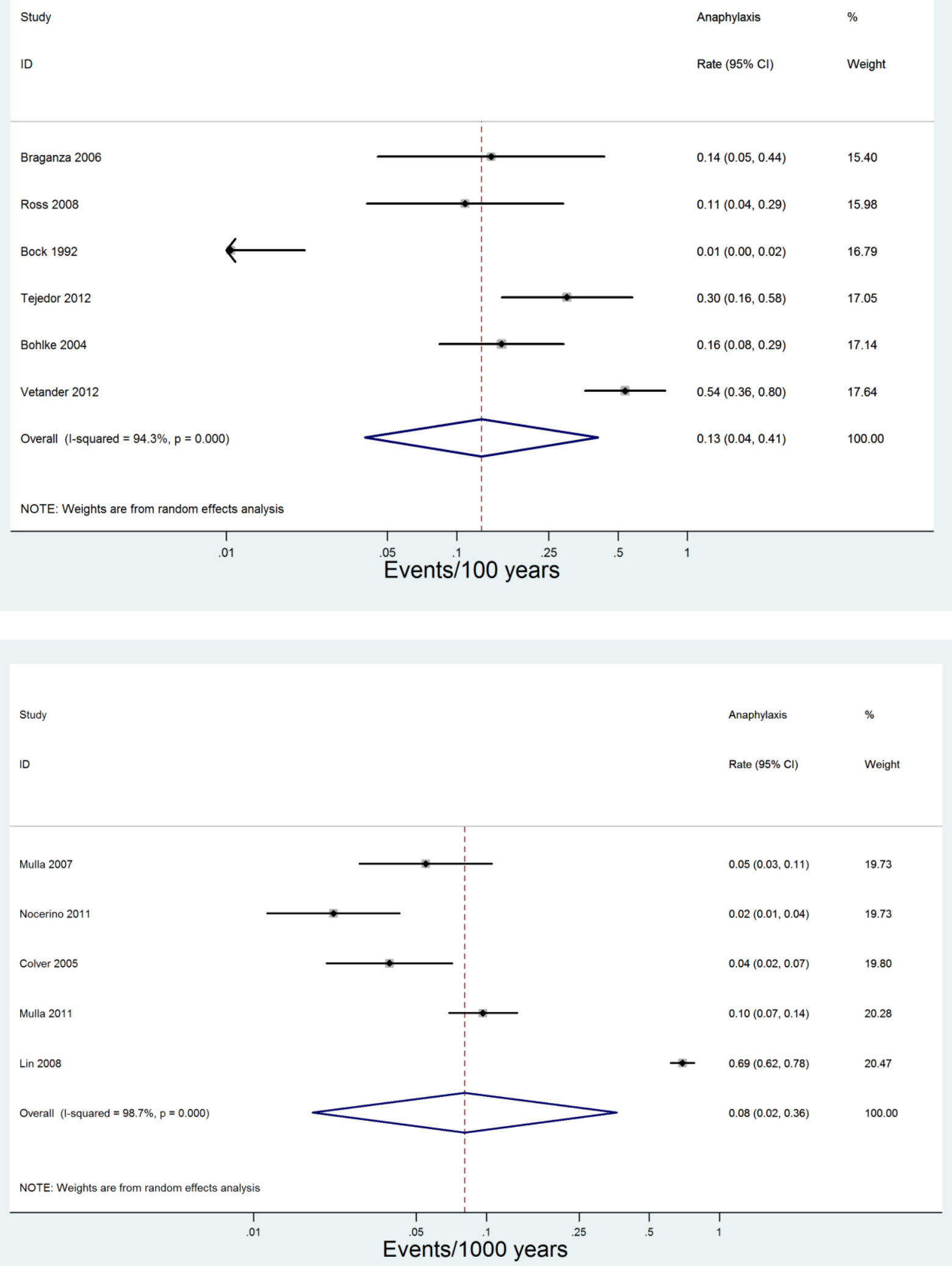

This article is protected by copyright. All rights reserved. 